Aingtera
Available online at: http://journal.uny.ac.id/index.php/litp
LingTera, 6 (1), 2019, 83-90

\title{
Submissiveness and resistance: Different paradigm between Indonesian Language and English
}

\author{
Jean Antunes Rudolf Zico Ma'u ${ }^{1}{ }^{*}$, Syarief Fajaruddin ${ }^{2}$, C. Bianrethny Monolga Lamahala ${ }^{3}$, \\ Choirul Fuadi ${ }^{1}$, Satya Perdana ${ }^{1}$, Ardi Ariyanto ${ }^{1}$ \\ ${ }^{1}$ Universitas Sanata Dharma. Jalan Affandi, Caturtunggal, Depok, Sleman, 55281, Indonesia \\ ${ }^{2}$ Universitas Negeri Yogyakarta. Jalan Colombo No. 1, Yogyakarta, 55281, Indonesia \\ ${ }^{3}$ Bielefeld University. Universitätsstraße 25, 33615 Bielefeld, Germany \\ *Corresponding author. Email: jaathrunzala6@gmail.com \\ Received: 12 March 2019; Revision: 13 May 2019; Accepted: 19 June 2019
}

\begin{abstract}
Translation plays greater role in recent time. This phenomenon especially occurs in efforts of bridging meanings and expressions across two different languages or more. In such effort, certainly there should be good understanding toward both the source language and the target language. Unfortunately, the bridge often cannot be constructed well due to the problems of non-equivalence. Therefore, throughout the study the researchers would like to elaborate the techniques that might be used for constructing the bridge between the two languages and the problems that occur during the translation project. In conducting the study, the researchers would strive to translate a copy of presidential decree by applying the selected techniques and by analysing the problems that might appear. The copy of presidential decree had been selected because the copy might not have been available in other languages especially in English. In addition, foreign people and institutions need to learn the decree since they might be doing business that has been associated to the energy in Indonesia. During the study, the researchers applied three techniques and found four problems during the translation project. As conclusion, the researchers found that the three translation techniques have been supporting one to another and the translation problems have been related to the Indonesian culture since the language and culture are inseparable.
\end{abstract}

Keywords: submissiveness, resistance, technique, non-equivalence

How to Cite: Ma'u, J., Fajaruddin, S., Lamahala, C., Fuadi, C., Perdana, S., \& Ariyanto, A. (2019). Submissiveness and resistance: Different paradigm between Indonesian language and English. LingTera, 6(1), 8390. doi:https://doi.org/10.21831/lt.v6i1.23966

This is an open access article under the CC-BY-SA license.

\section{INTRODUCTION}

Recent days, the era grows rapidly when transferring meanings and messages across languages becomes more crucial to deal with. Here, translation has become more important than ever (Nababan, 2007). This increasing importance might have been caused by the globalization. Moreover, English has been widely used as the language of global communication and trading activities (Knowles, Mughan, \& Lloyd-Reason, 2006; Selmier \& Oh, 2012). There is a well-known term called World English (Brutt-Griffler, 2002; McArthur, 2001, 2002) which refers to certain dialects that nonEnglish speakers have all around the globe. Due to these circumstances, English proficiency, as well as English mastery, becomes very important.

As a result, all local contents should be translated into English and all English contents should be translated into local language or vernacular. The latter does not only involve translation but also localization. By implying the term localization, the researchers would like to emphasize that the English content would not only be translated but also be adjusted to the target/local context. This adjustment involves changing the characters and also the screen, for example. Such effort can be well found in the case of electronics (notebook or laptop) sales. When such items will be sold in Asian regions such as People's Republic of China (PRC), 


\section{LingTera, 6 (1), 2019 - 84}

Jean Antunes Rudolf Zico Ma’u, Syarief Fajaruddin, Clara Bianrethny Monolga Lamahala, Choirul

Fuadi, Satya Perdana, Ardi Ariyanto

Japan, and South Korean, the manufacture process of notebook and laptop will involve inserting specific kanji characters so that it will support the use of the vernacular in the respective area. By doing so, a good sale revenue can be reserved.

Unfortunately, translation in some points has difficulties. These difficulties are related to certain problems between the source text and the target text. One of the apparent difficulties is the absence of the equivalent concept/ expression from the source text in the target text (Campbell, 1999; Hale \& Campbell, 2002). In order to explore more of these problems, the researchers would like to try translating a source text into a target text. The source text is Indonesian Language while the target text is English. Therefore, throughout the study, the researchers would like to present the translation techniques and also the translation problems in dealing with the project. In the same time, the researchers would also like to analyse the problems that appear during the translation project.

By translating a text from the source text into the target text and by analysing the problems that appear during the translation process, the researchers expect to find some valuable findings that can enrich the readers experience and understanding on translation. The researchers believe that these valuable findings will be useful for the readers, especially those who also work as translators. The researchers also hope that the valuable findings that can be found in the study will enrich the knowledge in the translation studies and will strengthen the memory bank of a translator.

In dealing with translations, certain aspects such as translation techniques and translation problems should be given attention. According to Vinay and Darbelnet (Hatim \& Munday, 2004, pp. 148-150) there are seven techniques that a translator may consult namely: borrowing, calque, literal translation, transposition, modulation, equivalence, and adaptation. These techniques can be grouped into two categories: the direct translation, consisting of borrowing, calque, and literal translation, and the indirect or oblique translation, consisting of transposition, modulation, equivalence, and adaptation. On the other hand, most of the translation problems are related to equivalence between the source text and the target text. Regarding the equivalence, according to Popovich (Bassnet, 2002, p. 32), there are four types of equivalence in translation equivalence namely: linguistic equivalence, paradigmatic equivalence, stylistic (translational) equivalence and textual (syntagmatic) equivalence. However, it is already a solid fact that two different languages share different linguistic systems, thus resulting in the case of nonequivalence. In relation to the problems of nonequivalence, Baker (2011, pp. 21-26) has classified those problems as follows: (a) culturespecific concepts; (b) the source language concept is not lexicalized in the target language; (c) the source language word is semantically complex; (d) the source and target languages make different distinctions in meaning; (e) the target language lacks superordinate; (f) the target language lacks a specific term (hyponym); (g) differences in physical or interpersonal perspective; (h) differences in expressive meaning; (i) differences in form; (j) different in frequency and purpose of using specific forms; and $(\mathrm{k})$ the use of loan words in the source text.

In order to describe the case that has been proposed in the study better, the researchers will translate a text from Indonesian language into English and to analyse the difficulties that might appear during the translation project. These difficulties actually might also be the problems in conducting any translation project. Thus, throughout this section the researchers will elaborate on the translation techniques and also the translation problems that will be useful in analyzing the translation result. At the end of the study, it is expected that the researcher will arrive at some important insights with regards to the translation from the source text into the target text.

\section{METHOD}

The text selected for the translation project in this research is the copy of the Presidential Decree Number 40/P 2016 regarding the ReEnactment of the Board of National Energy Membership for the Government Representative (Presiden Republik Indonesia, 2016). This research intends to elaborate the techniques used for constructing the bridge between the two languages and the problems that occur during the translation work. The reason behind this selection was that this copy might not available in other languages especially in English. In addition, foreign people and institutions need to learn and understand the decree since they might be doing business that have been associated to the energy in Indonesia. Therefore, it was important to translate this document and therefore translation can be the bridge for mutual understanding 


\section{LingTera, 6 (1), 2019 - 85}

Jean Antunes Rudolf Zico Ma'u, Syarief Fajaruddin, Clara Bianrethny Monolga Lamahala, Choirul Fuadi, Satya Perdana, Ardi Ariyanto

among the related institutions. The source text was written in Indonesian language and was translated to English. Both the original text and the translated text would be available in the appendix. In conducting the translation, the researcher also consulted to an example of a presidential decree written in English. This presidential decree was the one that had been written by Trump in September $24^{\text {th }}, 2017$, regarding the Presidential Proclamation Enhancing Vetting Capabilities and Processes for Detecting Attempted Entry into the United States by Terrorists and Other Public-Safety Threats (Trump, 2017). This president decree by Trump would also be available in the appendix.

\section{RESULTS AND DISCUSSIONS}

In this section, the researchers present and elaborate the findings gathered from conducting the translation of the source text, namely the copy of the Presidential Decree Number 40/P 2016 regarding the Re-Enactment of the Board of National Energy Membership for the Government Representative (Presiden Republik Indonesia, 2016). These findings were discussed in terms of the translation technique that had been employed and the translation problems that had been found during the project.

\section{Translation Technique}

In conducting the translation project, the researchers employed three techniques namely equivalence, transposition, and modulation. Each of these techniques was elaborated in the following sections.

\section{Equivalence}

The first technique that the researcher selected was equivalence. The reason why the researchers selected equivalence was that equivalence strived to pursue a good translation of the source text into the target text by looking for the immediate or the ready-to-use form as explained (Vinay \& Darbelnet, 1995). For the researchers, the technique was very useful in the first place since equivalence might assist a translator to find the immediate form in the target text that had similar meaning to the form in the source text. Therefore, in this study the researchers employed equivalence for several times since there were similarities between the source text and the target text under the same reason.
Table 1. Example of Equivalence

\begin{tabular}{lll}
\hline Source Text & Target Text & $\begin{array}{l}\text { Translation } \\
\text { Technique } \\
\text { Employed }\end{array}$ \\
\hline DENGAN & BY THE & Equivalence \\
RAHMAT & GRACE OF & \\
TUHAN YANG & GOD & \\
MAHA ESA & THE & \\
PRESIDEN & PRESIDENT & \\
REPUBLIK & OF THE & \\
INDONESIA & REPUBLIC OF & \\
& INDONESIA & \\
\hline
\end{tabular}

From the Table 1, it was apparent that the researcher decided to use the form "BY THE GRACE OF GOD" as the as the translation of "DENGAN RAHMAT TUHAN YANG MAHA ESA" instead of "BY THE GRACE OF LORD THE ALMIGHTY" because the Western people or the English-speaking people were more accustomed to the former than the latter form. On the other hand, the Indonesian people were accustomed to use the form "DENGAN RAHMAT TUHAN YANG MAHA ESA" or "BY THE GRACE OF LORD THE ALMIGHTY." However, this form was not that popular especially in the West. Instead, the form "BY THE GRACE OF GOD" was very popular. If one pays attention closely, then he or she might find that even in a dollar it was written "BY THE GRACE OF GOD." Therefore, in order to bridge the good understanding between the source text and the target text, the researcher had decided to use "BY THE GRACE OF GOD" as the translation for "DENGAN RAHMAT TUHAN YANG MAHA ESA."

\section{Transposition}

According to (Vinay \& Darbelnet, 1995), transposition involved replacing a word class with another but the replacement should not change the meaning of the source text. In other words, through the use of this technique a translator would be able to preserve the meaning of the source text in the target text although the form had been changed. Then, the researcher selected the technique because in some cases equivalence was not suitable for bridging the good understanding between the source text and the target text. As a result, the researcher should be flexible and this flexibility might be facilitated by the use of transposition. This case was presented in the following example. 


$$
\text { LingTera, } 6 \text { (1), } 2019 \text { - } 86
$$

Jean Antunes Rudolf Zico Ma'u, Syarief Fajaruddin, Clara Bianrethny Monolga Lamahala, Choirul

Fuadi, Satya Perdana, Ardi Ariyanto

Table 2. Example of Transposition

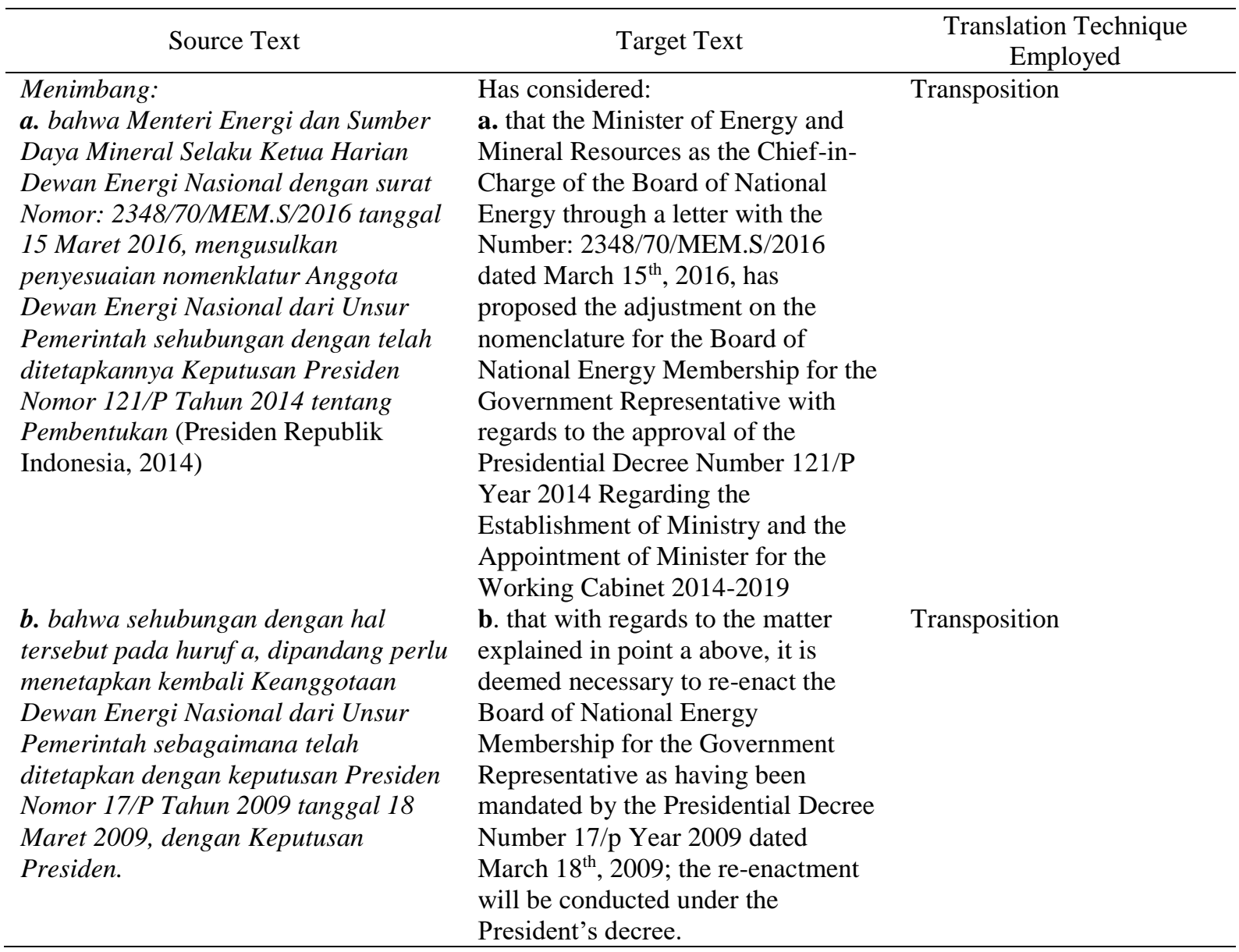

From the Table 2, it was apparent the researchers had decided to use present perfect tense form "Has considered" for the translation of the word "Menimbang". In the researchers' opinion, both forms shared the same active meaning ("to consider") yet they shared different meaning. Indonesian language did not acknowledge any tense whereas English emphasized the importance of using tense in written communication. As a result, the form "Menimbang" would not have time boundary and thus it implied that the form might carry the meaning of infinitive performance. Fortunately, such form might be facilitated by the use of present perfect tense. The idea that underlied the use of present perfect tense was that one activity might last from unclear time point up to the present time. Therefore, this idea can be applied to the translation project of the presidential decree because there was a possibility that the consideration upon the decree started from the unclear point of time yet it was still relevant to the present time.

\section{Modulation}

Vinay and Darbelnet (1995) defined modulation as a variation in the form of the message. This variation might be attained by changing the point of view. Any translator might apply this technique whenever he or she had difficulties to define an utterance that was grammatically correct according to the source text but was semantically incorrect according to the target text. This case was clearly apparent between Indonesian language and English. In Indonesian language, it was very acceptable to use the passive form in any occasion whereas in English it was quite awkward to use passive form for most of the time. This case might be related to the ideology between the two languages. Indonesian language tends to be submissive whereas the English tends to be resistant. As a result, Western people are more direct than Indonesian people. 


$$
\text { LingTera,6 (1), } 2019 \text { - } 87
$$

Jean Antunes Rudolf Zico Ma'u, Syarief Fajaruddin, Clara Bianrethny Monolga Lamahala, Choirul

Fuadi, Satya Perdana, Ardi Ariyanto

Table 3. Example of Modulation

\begin{tabular}{llc}
\hline \multicolumn{1}{c}{ Source Text } & \multicolumn{1}{c}{ Target Text } & $\begin{array}{c}\text { Translation } \\
\text { Technique Employed }\end{array}$ \\
\hline Presiden Republik Indonesia & The President of the Republic of Indonesia & Modulation \\
SALINAN & COPY & \\
KEPUTUSAN PRESIDEN REPUBLIK & THE PRESIDENTIAL DECREE & Modulation \\
INDONESIA & NUMBER 40/P YEAR 2016 BY THE & \\
NOMOR 4O/P TAHUN 2016 & PRESIDENT OF THE REPUBLIC OF & \\
& INDONESIA & Modulation \\
TENTANG & REGARDING & \\
PENETAPAN KEMBALI & THE RE-ENACTMENT OF THE & Modulation \\
KEANGGOTAAN DEWAN ENERGI & BOARD OF NATIONAL ENERGY & \\
NASIONAL & MEMBERSHIP FOR THE & \\
DARI UNSUR PEMERINTAH & GOVERNMENT REPRESENTATIVE & \\
\hline
\end{tabular}

Table 4. Example of Culture-Specific Concept Case

\begin{tabular}{|c|c|c|}
\hline \multirow{4}{*}{$\begin{array}{l}\text { Source Text } \\
\text { MEMUTUSKAN: }\end{array}$} & Target Text & Comparison \\
\hline & AND THEREFORE THROUGH THE & NOW, THEREFORE, I, DONALD J. \\
\hline & CONSIDERATION AND THE & TRUMP, by the authority vested in me by the \\
\hline & REFERENCE HAS DECIDED TO & $\begin{array}{l}\text { Constitution and the laws of the United States } \\
\text { of America }\end{array}$ \\
\hline
\end{tabular}

From the Table 3, tit was apparent that the researcher decided to translate the form "PENETAPAN KEMBALI KEANGGOTAAN DEWAN ENERGI NASIONAL DARI UNSUR PEMERINTAH" into "THE RE-ENACTMENT OF THE BOARD OF NATIONAL ENERGY MEMBERSHIP FOR THE GOVERNMENT REPRESENTATIVE." The decision was influenced by the ideology that the two languages had. The term "DARI" had passive meaning as implied by its immediate constituent in English "FROM." Regarding the fact that English was resistant, meaning it preferred using more active forms than passive forms, the researchers should replace the term "FROM" with "FOR" in order to show the active meaning.

\section{Translation Problems}

During the project completion, the researcher found several problems that caused the difficulties within the translation process. Referring to Baker (2011), the problems were culture-specific concept, the source language concept was not lexicalized in the target language, the source word was semantically complex, and differences in expressive meaning. Each of these problems will be elaborated in the following sections.

\section{Culture-specific concept}

The culture-specific concept was one of the most difficult problems that the researchers should tackle during the translation project. In the researcher's opinion, the concept of Indonesian language was quite difficult to be translated into that of English. The reason was that, as having been explained in the previous section, Indonesian language inclined to be submissive and this submissiveness was quite apparent in the life of Indonesian people. Indonesian people inclined to endure rather than to resist the situations that they experienced especially the difficult ones. On the contrary, the Western people, such as English and American, inclined to resist rather to endure the situations that they experienced. This case was well-presented in the Table 4.

The concept of Indonesian language (Table 4) had indeed been translated into English but it was still semantically submissive in a sense that the President of the Republic of Indonesia should wait for a long time with so many consideration prior to the final decision. This concept was totally different from the presidential decree approved by the recently elected President of the United States of America Donald J. Trump.

From the above comparison, it was clear that the Indonesian language and English had completely different ideology. Even if the Indonesian concept was forced to be adjusted to the American one, it would be deemed arrogant and be considered not displaying the true Indonesian values. As a result, the only possible way was to preserve the Indonesian concept in English with the hope that the translation can be easily understood by the English speakers. 


\section{LingTera, 6 (1), 2019 - 88}

Jean Antunes Rudolf Zico Ma'u, Syarief Fajaruddin, Clara Bianrethny Monolga Lamahala, Choirul Fuadi, Satya Perdana, Ardi Ariyanto

\section{The Source Language Concept was not lexicalized in the Target Language}

The second problem was more or less similar to the first problem yet it was more detailed. In the translation project of this study, the researcher found that the translator should add several words in order to bridge the concept from the source text into the target text. This effort had been more difficult because the source language concept had some kind of missing link to the next sections. This case can be seen in the Table 5.

From the Table 5, it was clear that the Indonesian concept in the decree had been lack of conjunction. The lack of conjunction was unacceptable in English since English had coherence in its texts. Without good coherence, it would be impossible to create a good English text. Therefore, in the translated version of the decree the researchers have brought the coherence into surface by adding some words that provide better understanding toward the decree.

\section{The source word was semantically complex}

The source word in the text that had been translated was also semantically complex. As mentioned in the discussion of culture-specific context, Indonesian language inclined to be submissive. As a consequence, Indonesian language accepted more passive forms than active ones. In certain cases, the use of these passive forms did not entail the use of clear subject. Certainly, such problem urged any translator to either create the subject for the passive form by paying attention closely to the context or replace the passive form with appropriate alternative such as noun for example. The following example describes this situation well.

From the Table 6, it was apparent that the word "dinyatakan," meaning "to be stated," had the passive form of the word "menyatakan," meaning "to state." As one might see, the form "to state" was more acceptable in English than the form "to be stated." Therefore, the above sentence should be turned into the active form. The use of the active form might be clearly observed in the comparison and such use resulted in stronger power. Unfortunately, the action might be performed because the previous point was not equipped with the conjunction and even the first point of this decree did not display any subject. In order to overcome this situation, the researchers decided to replace all of the source words by the nouns in the target words. Through the replacement, the researcher had successfully simplified the source forms into the target forms so that he might bridge the two languages well.

Table 5. Example for the Case that the Source Language Concept is not Lexicalized in the Target Language

\begin{tabular}{|c|c|c|}
\hline Source Text & Target Text & Comparison \\
\hline Menetapkan: & Approve: & In Executive Order 13780 of March 6, \\
\hline KEPUTUSAN PRESIDEN & THE PRESIDENTIAL DECREE & 2017 (Protecting the Nation from Foreign \\
\hline TENTANG PENETAPAN & REGARDING THE RE- & Terrorist Entry into the United States), on \\
\hline$K E M B A L I$ & ENACTMENT OF THE BOARD OF & the recommendations of the Secretary of \\
\hline KEANGGOTAAN DEWAN & NATIONAL ENERGY & Homeland Security and the Attorney \\
\hline ENERGI NASIONAL & MEMBERSHIP FOR THE & General, I ordered a worldwide review of \\
\hline DARI UNSUR & GOVERNMENT & whether, and if so what, additional \\
\hline PEMERINTAH. & REPRESENTATIVE ALONG WITH & information would be needed from each \\
\hline \multirow[t]{3}{*}{ KESATU ... } & FOUR POINTS THAT WILL BE & foreign country to assess adequately \\
\hline & ELABORATED AS FOLLOWS & whether their nationals seeking to enter the \\
\hline & ONE . & $\begin{array}{l}\text { United States pose a security or safety } \\
\text { threat. }\end{array}$ \\
\hline
\end{tabular}

Table 6. Example for the Case that the Source Word is Semantically Complex

\begin{tabular}{|c|c|c|}
\hline Source Text & Target Text & Comparison \\
\hline KEDUA: & TWO: & But until they satisfactorily address the identified \\
\hline Dengan ditetapkannya & The withdrawal of & inadequacies, I have determined, on the basis of \\
\hline Keputusan Presiden ini, & the First Decision on & ndations from the Secretary of Homeland \\
\hline maka Diktum PERTAMA & the Presidential & Security and other members of my Cabinet, to impose \\
\hline Keputusan Presiden Nomor & Decree Number $17 / \mathrm{P}$ & certain conditional restrictions and limitations, as set \\
\hline 17/P Tahun 2009 tanggal 18 & Year 2009 dated & forth more fully below, on entry into the United \\
\hline $\begin{array}{l}\text { Maret } 2009 \text {, dinyatakan } \\
\text { tidak berlaku. }\end{array}$ & March $18^{\text {th }}, 2009$. & $\begin{array}{l}\text { States of nationals of the countries identified in } \\
\text { section } 2 \text { of this proclamation. }\end{array}$ \\
\hline
\end{tabular}




\section{Ling Tera, 6 (1), 2019 - 89}

Jean Antunes Rudolf Zico Ma'u, Syarief Fajaruddin, Clara Bianrethny Monolga Lamahala, Choirul

Fuadi, Satya Perdana, Ardi Ariyanto

Table 7. Example for the case of Differences in Expressive Meaning

\begin{tabular}{|c|c|c|}
\hline Source Text & Target Text & Comparison \\
\hline Ditetapkan di Jakarta & Approved in Jakarta & IN WITNESS WHEREOF, I have hereunto set \\
\hline pada tanggal 1 April 2016 & On April $1^{\text {st }}, 2016$ & my hand this twenty-fourth day of September, in \\
\hline PRESIDEN REPUBLIK & THE PRESIDENT OF & the year of our Lord two thousand seventeen, and \\
\hline INDONESIA, & THE REPUBLIC OF & of the Independence of the United States of \\
\hline$t t d$. & INDONESIA & America the two hundred and forty-second. \\
\hline JOKO WIDODO & Signed & DONALD J. TRUMP \\
\hline & JOKO WIDODO & \\
\hline
\end{tabular}

\section{Differences in Expressive Meaning}

The differences in expressive meaning had also caused another significant problem during the translation project. As preceding discussed, Indonesian language inclined to accept more passive forms than the active forms. Even in approving a decree, the President inclined to use the passive form rather than the active form. Certainly, this situation was different than in English. Since English is more resistant, with the "I" ideology, it inclined to prioritize the use of active form even in its expressive meaning. This case was well depicted in the Table 7.

The use of active form as having been implied by the comparison certainly resulted in stronger sense of power. The stronger sense of power was heavily important especially in the context of presidential decree. Therefore, any presidential decree that had the active form will certainly exert more power. Unfortunately, this idea might not be forced into the Indonesian context because, once again, Indonesian language was submissive rather than resistant. Due to this situation, the researcher as a translator had decided to preserve the meaning or the local content in the translation in order that the sense of Indonesian language would not be lost.

\section{CONCLUSIONS}

Based on the process in conducting the translation project and also the discussions, the researchers come to draw several conclusions. First, there are three techniques that the translator has selected. The first technique is equivalence because the researchers perceive that there is some sort of equivalent language structure between the source text and the target text. Then, the second technique is transposition while the third technique is modulation. These two techniques have been selected in order to support the use of equivalence because the researchers in some points during the translation project have found certain forms that should be translated beyond the replacement of immediate forms between the source text and target text.

Second, the researchers investigate four problems that cause the non-equivalence between the source text and the target text during the translation project. These problems are: (a) culture-specific concept; (b) the source specific concept is not lexicalized in the target language; (c) the source word is semantically complex; and d) differences in expressive meaning. All of these problems have been related mainly to the culture of Indonesian people since language and culture are inseparable. Therefore, in order to craft a good translation product from Indonesian language to English a translator must have good understanding between both languages so that he or she can choose the appropriate immediate forms. In addition, he or she should also preserve the original meaning so that the local content of Indonesian language is not lost in the translation product. As concluding remarks, the researchers expect that the results of this study will enrich the knowledge and will expand the memory bank of any translator especially the translator dealing with the translation from Indonesian language to English in the meantime.

\section{REFERENCES}

Baker, M. (2011). In other words: A coursebook on translation. Routledge.

Bassnet, S. (2002). Translation studies. Routledge.

Brutt-Griffler, J. (2002). World English: A study of its development (Vol. 34). Multilingual Matters.

Campbell, S. (1999). A cognitive approach to source text difficulty in translation. Target, 11(1), 33-63. https://doi.org/10.1075/target.11.1.03cam

Hale, S. B., \& Campbell, S. (2002). The interaction between text difficulty and translation accuracy. Babel, 48(1), 14-33. https://doi.org/10.1075/babel.48.1.02hal

Hatim, B., \& Munday, J. (2004). Translation: An 


\section{LingTera, 6 (1), 2019 - 90}

Jean Antunes Rudolf Zico Ma'u, Syarief Fajaruddin, Clara Bianrethny Monolga Lamahala, Choirul

Fuadi, Satya Perdana, Ardi Ariyanto

advanced resource book. Psychology Press.

Knowles, D., Mughan, T., \& Lloyd-Reason, L. (2006). Foreign language use among decision-makers of successfully internationalised SMEs. Journal of Small Business and Enterprise Development, 13(4), $620-641$. https://doi.org/10.1108/146260006107057 87

McArthur, T. (2001). World English and world Englishes: Trends, tensions, varieties, and standards. Language Teaching, 34(1), 120.

https://doi.org/10.1017/S02614448000160 62

McArthur, T. (2002). The Oxford guide to world English. Oxford University Press.

Nababan, M. R. (2007). Aspek genetik, objektif, dan afektif dalam penelitian penerjemahan. Linguistika: Buletin Ilmiah Program Magister Linguistik Universitas Udayana, 14. Retrieved from https://ojs.unud.ac.id/index.php/linguistik a/article/view/77

Presiden Republik Indonesia. keputusan Presiden Republik Indonesia Nomor 121/P tahun 2014 tentang pembentukan kementerian dan pengangkatan menteri Kabinet Kerja peridode tahun 2014-2019, Pub. L. No.
121 (2014). Indonesia.

Presiden Republik Indonesia. Keputusan Presiden Republik Indonesia nomor 40/P tahun 2016 tentang penetapan kembali keanggotaan dewan energi nasional dari unsur pemerintah, Pub. L. No. 40 (2016). Indonesia.

Selmier, W. T., \& Oh, C. H. (2012). International business complexity and the internationalization of languages. Business Horizons, 55(2), 189-200. https://doi.org/10.1016/j.bushor.2011.11.0 06

Trump, D. J. (2017). Presidential proclamation enhancing vetting capabilities and processes for detecting attempted entry into the United States by terrorists or other public-safety threats. Retrieved July 26, 2018 , from https://www.whitehouse.gov/presidentialactions/presidential-proclamationenhancing-vetting-capabilities-processesdetecting-attempted-entry-united-statesterrorists-public-safety-threats/

Vinay, J.-P., \& Darbelnet, J. (1995). Comparative stylistics of French and English: A methodology for translation (Vol. 11). John Benjamins Publishing. 